STRUCTURAL

BIOLOGY

ISSN 2059-7983

Keywords: introduction; neutron scattering; macromolecular deuteration.

Acta Crystallographica Section D STRUCTURAL BIOLOGY

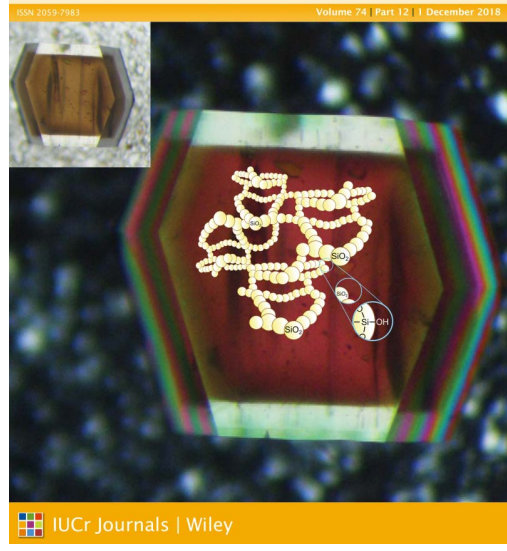

(C) 2018 International Union of Crystallography

\section{Neutron scattering for the study of biological systems - major opportunities within a rapidly changing landscape}

\author{
V. Trevor Forsyth ${ }^{\mathrm{a}, \mathrm{b} *}$ and Peter Moody \\ ${ }^{\text {a} P a r t n e r s h i p ~ f o r ~ S t r u c t u r a l ~ B i o l o g y, ~ I n s t i t u t ~ L a u e-L a n g e v i n, ~} 6$ rue Jules Horowitz, 38042 Grenoble CEDEX 9 France,

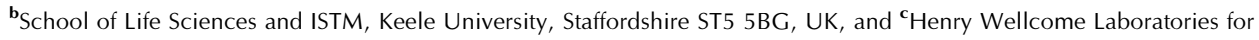 \\ Structural Biology, Leicester Institute for Structural and Chemical Biology and Department of Molecular and Cell Biology, \\ University of Leicester, Lancaster Road, Leicester LE1 7RH, UK. *Correspondence e-mail: tforsyth@ill.fr
}

Neutrons have become an increasingly powerful and sophisticated tool in structural biology over the last 10-15 years. Major improvements in sources, instrumentation and sample preparation have radically changed the scope of neutron scattering approaches for studies of biological macromolecules in solutions, crystals and partially ordered systems. This is shown by a wide range of high-impact publications that are steadily uncovering novel aspects of biological structure and dynamics that are not accessible to other methods. These developments have come at a time of fundamental change in the scientific landscape, with ground-breaking developments in the use of free-electron laser (FEL) facilities throughout the world, major improvements in the resolution of cryoelectron microscopy, as well as key developments at synchrotron X-ray beam sources. In parallel with this, and at least in part motivated by a drive to maximize the benefits of strongly complementary central facilities (a number of which are co-located), there has been increasing emphasis on the use of integrated and multi-technique approaches that span resolution boundaries and add to the interpretation of results from individual methods - each of which have their own limitations. All of this is occurring while Europe is planning major upgrades to its existing steady-state neutron beam facilities in Grenoble (ILL) and Munich (FRM-II), as well as the ISIS pulsed facility on the RutherfordAppleton Laboratory site in the UK. In the USA, powerful steady-state sources exist at Oak Ridge National Laboratory (ORNL) and at NIST in Washington, and the SNS facility at ORNL is now fully operational. The J-PARC facility in Japan is also active in the field of life sciences as is the ANSTO facility in Australia. In addition, the new ESS spallation facility is currently being built in Sweden and will be the most powerful source of its type in the world. It will occupy a central international role within a highly prominent consortium that is dedicated to the joint exploitation of neutron and X-ray science both in Scandinavia and internationally. The potential of these major developments has been highlighted at a number of recent workshops that have demonstrated the current scope of the techniques involved and helped identify future directions and needs. The Neutrons in Structural Biology (NISB) workshop (Grenoble, 2017), the NSF Workshop on Progress and Prospects in Neutron Scattering for the Biological Sciences [Alexandria, Virginia, USA, 2018 - see Ashkar et al. (2018)] and the ILL-ESS Users Meeting (Grenoble, 2018) all touched on these issues in different ways, and this is reflected in the articles of this special issue.

One of the most widely used neutron approaches in the study of biological systems is small-angle neutron scattering (SANS). SANS can be deployed to study the solution structures of macromolecular systems and is conceptually rather similar to its X-ray analogue (small-angle X-ray scattering - SAXS) in that it provides low-resolution threedimensional information on molecular shape and without the need for crystallization. This type of information may be very important in the study of large macromolecules and complexes, and in carrying out parametric studies that probe the structural consequences of (for example) ligand interactions. However, in contrast to SAXS, SANS has the additional capability to exploit solvent contrast variation so that regions of a macromolecule/complex/system having different scattering length densities can be distinguished and modelled. This can be extremely powerful in establishing structure-function relationships or in the elucidation of structures when the native sample habit is problematic either for sample preparation or for analysis. Good examples of the latter category are provided by recent studies where membrane proteins have been studied in 
'stealth nanodiscs' (Maric et al., 2014, 2015) in which sophisticated deuteration techniques permit complete solvent matchout of membrane components so that important membrane proteins can be imaged in a relevant native environment (e.g. Josts et al., 2018; Nitsche et al., 2018). Future potential in this area is very high and enhanced crucially by the availability of advanced sample deuteration regimes (Haertlein et al., 2016) and sample handling capabilities (Jordan et al., 2016; Johansen et al., 2018). In addition, work of the type described by Weinrich \& Worcester (2018, this issue) shows how SANS can be used to study domain mixing in ternary lipid mixtures of relevance to anaesthesia, and the paper by Arunmanee (2018, this issue) demonstrates how amphipols can be exploited for the study of membrane protein structure.

Neutron protein crystallography (NMX) is also changing rapidly, with major developments at the ILL (where a second Laue instrument is planned to deal with increased demand), FRM-II and at ORNL. The complementarity with X-ray macromolecular crystallography (MX) is direct, with important information on hydration and protonation states emerging from Laue and monochromatic neutron diffractometers. Water is an integral and vital part of macromolecular structure; X-rays are poor at describing water molecules as they are only usually seen as oxygen atoms so that (for example) it is hard to distinguish hydroxyl groups, water molecules or hydronium ions on the basis of X-ray data alone. Given the importance of hydration and hydrogen bonding to biomolecular structure, stability and flexibility, the ability of neutron diffraction to resolve the location of hydrogen atoms is of major importance in understanding these interactions and in providing exploitable information on ligand/drug interactions with proteins (Kovalevsky et al., 2010; Howard et al., 2016; Dajnowicz et al., 2017; Kwon et al., 2018; Vandavasi et al., 2018; Yee et al., 2019). In addition, highly structured water/hydronium networks that link to redox proteins may be implicated in tautomeric shifts and proton hopping associated with charge-transfer processes. Here neutrons play two crucial roles - firstly in allowing detailed structural studies of oxidized and reduced forms of the protein that usually suffer serious radiation damage during X-ray analyses, and secondly by allowing details of the potential charge-transfer networks to be imaged at atomic resolution (Cuypers et al., 2013). New approaches for neutron crystallography include cryo-trapping of structural intermediates (Casadei et al., 2014; Kwon et al., 2016) and the use of $\mathrm{D}_{2} \mathrm{O} / \mathrm{H}_{2} \mathrm{O}$ solvent back exchange to gather quantitative positional information on protein stability, as alluded to by Yee et al. (2017) and Ashkar et al. (2018). A further crucial challenge for the future is addressing the single biggest bottleneck in NMX - large crystal growth. This issue was a very notable theme at the Grenoble workshop, spurred on by the SINE2020 initiative for macromolecular crystallogenesis that links groups at the ILL, FRM-II and ESS. The articles of Gavira et al. (2018) and of Sorensen et al. (2018), raise crucial issues in this area.

Another prominent neutron scattering approach that has particular relevance to the study of membranous systems is neutron reflection (NR). NR can be used to study the interaction of model membranes with proteins or peptides in a situation of particular importance to crucially important biological functions (e.g. transport processes, protein folding) (see for example Luchini et al., 2016). As noted by Hoogerheide et al. (2018), the lipid interactions associated with integral membrane proteins (IMPs) are of central interest. Other important issues are the relationship between cholesterol and lipids (Waldie et al., 2017) and also more complex systems such as the HDL/LDL exchange processes and their relationship to atherosclerosis. The arguments concerning the deployment of deuteration methods in NR studies are in concept similar to those for SANS (Haertlein et al., 2016) and important use can be made of novel labelling approaches such as the biosynthesis of per-deuterated and matchout deuterated cholesterol (Moulin et al., 2018). One recurrent issue is the fact that while there is a good natural contrast between lipid fatty acids that can be exploited using contrast variation, the lipid head groups have a significantly different scattering length density (SLD) and may be difficult to distinguish from protein components. The use of deuterated protein in NR studies of this type alleviates this problem by providing a markedly increased contrast; furthermore the approach used by the Josts $e t$ al. (2018) and Nitsche et al. (2018) for SANS studies of stealth nanodiscs exploits a biosynthesis regime in which the lipid head and tail groups are closely matched (Maric et al., 2014, 2015). A further important issue for NR studies of membranes is the development and characterization of good membrane models for different types of system - see Florek et al. (2018).

While all of the techniques mentioned above are vastly different in the way they relate to different sample habits, they are all structural approaches that yield little information on molecular motions that are of central importance to biological function. A full understanding of the way proteins work in various contexts, both in vitro and in vivo, requires a strong linkup between structural methods and those that probe dynamics. Good examples that illustrate the importance of dynamics in biology are protein-protein interactions, proteinligand interactions and the existence of intrinsically disordered proteins (Grimaldo et al., 2018). Neutron scattering allows powerful insights into molecular motions in proteins for timescales ranging from the femtosecond to the microsecond. As noted by Smith et al. (2018), these approaches are most effective when combined with computational modelling approaches. Deuteration approaches can also be used in the study of protein dynamics and has been widely used in hydrogen incoherent scattering studies where the use of either deuterated solvent or deuterated protein can be used to distinguish the dynamics of the two parts of the system.

One of the common themes to emerge from the wide range of presentations at these workshops has been the fact that neutron methods, like most approaches, are at their best when combined with other methods. While there was early recognition of this in the co-location of neutron and synchrotron X-ray beam sources on sites such as Grenoble, Harwell and PSI, the inter-disciplinarity that might have been anticipated at the inception of these joint projects took some time to 
develop. One of the first such initiatives to pursue this vision was the Partnership for Structural Biology (PSB, http:// www.psb-grenoble.eu/), which was founded on the European Photon and Neutron (EPN, http://www.epn-campus.eu/) campus in Grenoble and brought together a very substantial body of science and expertise from amongst the Institut LaueLangevin (ILL) neutron source, the European Synchrotron Radiation Facility (ESRF), the Institut de Biologie Structurale (IBS) and the Grenoble EMBL Outstation. In addition to the central facility provision of neutron and X-ray beams, this partnership, founded in 2002, now supports some 23 technical platforms including high-field NMR, cryo-electron microscopy and mass spectrometry. In a similar vein the Research Complex at Harwell ( $\mathrm{RCaH})$ was set up to exploit the capabilities of X-rays, neutrons and advanced laser facilities. Most recently the Forschungszentrum Jülich, Germany, has decided to establish a Research Center - JUSTRUCT dedicated to structural biology. This will bring together NMR, cryo-TEM, synchrotron-X-ray and neutron diffraction as complementary methods to address challenging questions in protein structure analysis. This trend towards increasingly integrated exploitation of capabilities that would not always lie within the reach of individual research groups is now starting to extend well beyond access to major central facilities such as neutron sources, providing a rapidly growing framework within which the centralization provided by facility operators can be used to dramatically extend the added value for the user science projects they support. This holistic growth augurs well for current and future science at these facilities and for the development of the facilities themselves.

\section{Acknowledgements}

The authors acknowledge the ILL, ISIS and ESS for the support of the Neutrons in Structural Biology Meeting in Grenoble and the EU for the support of the SINE2020 grant under framework for the support of scientific contributions at this meeting. The NSF Workshop on Progress and Prospects in Neutron Scattering for the Biological Sciences in Alexandria, Virginia, USA was funded by the Division of Molecular and Cellular Biosciences of the US National Science Foundation.

\section{References}

Arunmanee, W., Heenan R. K. \& Lakey J. H. (2018). Acta Cryst. D74, 1192-1199.

Ashkar, R., Bilheux, H., Bordallo, H., Briber, R., Callaway, D. J. E., Cheng, X., Chu, X.-Q., Curtis, J. E., Dadmun, M., Fenimore, P., Fushman, D., Gabel, F., Gupta, K., Heberle, F., Heinrich, F., Hong, L., Katsaras, J., Kelman, Z., Kharlampieva, E., Kneller, G., Kovalevsky, A., Krueger, S., Langan, P., Lieberman, R., Liu, Y., Loesche, M., Lyman, E., Mao, Y., Marino, J., Mattos, C., Meilleur, F., Moody, P., Nickels, J. D., O’Dell, W. B., O’Neill, H., Perez-Salas, U., Peters, J., Petridis, L., Sokolov, A. P., Stanley, C., Wagner, N., Weinrich, M., Weiss, K., Wymore, T. \& Smith, J. C. (2018). Acta Cryst. D74, 1129-1168.

Casadei, C. M., Gumiero, A., Metcalfe, C. L., Murphy, E. J., Basran, J., Concilio, M. G., Teixeira, S. C. M., Schrader, T. E., Fielding, A. J., Ostermann, A., Blakeley, M. P., Raven, E. L. \& Moody, P. C. E. (2014). Science, 345, 193-197.

Cuypers, M. G., Mason, S. A., Blakeley, M. P., Mitchell, E. P. \& Forsyth, V. T. (2013). Angew. Chem. 52, 1022-1025.
Dajnowicz, S., Johnston, R. C., Parks, J. M., Blakeley, M. P., Keen, D. A., Weiss, K. L., Gerlits, O., Kovalevsky, A. \& Mueser, T. C. (2017). Nat. Commun. 8, 955.

Florek, O. B., Clifton, L. A., Wilde, M., Arnold, T., Green, R. J. \& Frazier, R. A. (2018). Acta Cryst. D74, 1233-1244.

Gavira, J., Conejero-Muriel, M. \& Delgado-Lopez, J. M. (2018). Acta Cryst. D74, 1200-1207.

Grimaldo, M., Lopez, H., Beck, C., Roosen-Runge, F., Moulin, M., Devos, J. M., Laux-Lesourd, V., Haertlein, M., Devela, S., Schweins, R., Mariani, A., Zhang, F., Barray, J.-L., Oettel, M., Forsyth, V. T., Seydel, T. \& Schreiber, F. (2018). Proc. Natl Acad. Sci. USA. Submitted.

Haertlein, M., Moulin, M., Devos, J. M., Laux, V., Dunne, O. \& Forsyth, V. T. (2016). Methods Enzymol. 566, 113-157.

Hoogerheide, D. P., Yu, S., Kuszak, A. J., Buchanan, S. K., Rostovtseva, T. K. \& Nanda, H. (2018). Acta Cryst. D74, 1219-1232.

Howard, E. I., Guillot, B., Blakeley, M. P., Haertlein, M., Moulin, M., Mitschler, A., Cousido-Siah, A., Fadel, F., Valsecchi, W. M., Tomizaki, T., Petrova, T., Claudot, J. \& Podjarny, A. (2016). IUCrJ, 3, 115-126.

Johansen, N. T., Pedersen, M. C., Porcar, L., Martel, A. \& Arleth, L. (2018). Acta Cryst. D74, 1178-1191.

Jordan, A., Jacques, M., Merrick, C., Devos, J., Forsyth, V. T., Porcar, L. \& Martel, A. (2016). J. Appl. Cryst. 49, 2015-2020.

Josts, I., Nitsche, J., Maric, S., Mertens, H. D., Moulin, M., Haertlein, M., Prevost, S., Svergun, D. I., Busch, S., Forsyth, V. T. \& Tidow, H. (2018). Structure, 26, 1072-1079.

Kovalevsky, A. Y., Hanson, L., Fisher, S. Z., Mustyakimov, M., Mason, S. A., Forsyth, V. T., Blakeley, M. P., Keen, D. A., Wagner, T., Carrell, H. L., Katz, A. K., Glusker, J. P. \& Langan, P. (2010). Structure, 18, 688-699.

Kwon, H., Basran, J., Casadei, C. M., Fielding, A. J., Schrader, T. E., Ostermann, A., Devos, J. M., Aller, P., Blakeley, M. P., Moody, P. C. E. \& Raven, E. L. (2016). Nat. Commun. 7, 13445.

Kwon, H., Langan, P. S., Coates, L., Raven, E. L. \& Moody, P. C. E. (2018). Acta Cryst. D74, 792-799.

Luchini, A., Gerelli, Y., Fragneto, G., Nylander, T., Pálsson, G. K., Appavou, M. S. \& Paduano, L. (2017). Colloids Surf. B Biointerfaces, 151, 76-87.

Maric, S., Skar-Gislinge, N., Midtgaard, S., Thygesen, M. B., Schiller, J., Frielinghaus, H., Moulin, M., Haertlein, M., Forsyth, V. T., Pomorski, T. G. \& Arleth, L. (2014). Acta Cryst. D70, 317-328.

Maric, S., Thygesen, M. B., Schiller, J., Marek, M., Moulin, M., Haertlein, M., Forsyth, V. T., Bogdanov, M., Dowhan, W., Arleth, L. \& Pomorski, T. G. (2015). Appl. Microbiol. Biotechnol. 99, 241-254.

Moulin, M., Strohmeier, G. A., Hirz, M., Thompson, K. C., Rennie, A. R., Campbell, R. A., Pichler, H., Maric, S., Forsyth, V. T. \& Haertlein, M. (2018). Chem. Phys. Lipids, 212, 80-87.

Nitsche, J., Josts, I., Heidemann, J., Mertens, H. D., Maric, S., Moulin, M., Haertlein, M., Busch, S., Forsyth, V. T., Svergun, D. I., Uetrecht, C. \& Tidow, H., (2018). Commun. Biol. 1, 206.

Smith, J., Tan, P., Petridis, L. \& Hong, L. (2018). Ann. Rev. Biophys. 47, 335-354.

Sorensen, T. L.-M., Hjorth-Jensen, S. J., Oksanen, E., Andersen, J. L., Olesen Moller, J. V. \& Nissen, P. (2018). Acta Cryst. D74, 12081218.

Vandavasi, V., Blakeley, M. P., Keen, D., Hu, L., Huang, Z. \& Kovalevsky, A. (2018). Structure, 26, 1645-1650.

Waldie, S., Lind, T. K., Browning, K., Moulin, M., Haertlein, M., Forsyth, V. T., Luchini, A., Strohmeier, G. A., Pichler, H., Maric, S. \& Cárdenas, M. (2017). Langmuir, 34, 472-479.

Weinrich, M. \& Worcester, D. L. (2018). Acta Cryst. D74, 1169-1177. Yee, A. W., Blakeley, M. P., Moulin, M., Haertlein, M., Mitchell, E. \& Forsyth, V. T. (2017). J. Appl. Cryst. 50, 660-664.

Yee, A. W., Aldeghi, M., Blakeley, M. P., Ostermann, A., Mas, P., Moulin, M., de Sanctis, D., Bowler, M.W., Mueller-Dieckmann, C., Mitchell, E. P., Haertlein, M., de Groot, B. L., Boeri Erba, E. \& Forsyth V. T. (2019). Nat. Commun. In the press. 